\title{
Short-term versus Long-term Benefits: Balanced Sustainability Framework and Research Propositions
}

\begin{abstract}
Sustainability research has been expanding rapidly during recent decades. Such research takes various forms with the identification of mixed results. Even though there are several review articles on sustainability with valuable insights, the time dimension aspect of sustainability is totally missing in addition to lack of well-developed framework. This paper systematically reviews previous sustainability studies published in the refereed scientific journals for the past two decades to understand the evolution of sustainability issues in the business context and solutions proposed until now. The study categorizes the popular sustainability practices into short- and long-term practices based on the time effect, and link them with different forms of organizational capabilities and sustainability performance. The paper further proposes a two-dimensional sustainability framework that incorporates practices, capabilities and performance, and the balancing issues between short- and long-term sustainability. At the end, it suggests potential research directions for future research as well.
\end{abstract}

\section{Graphical abstract}

Review of sustainability

theories, practices,

capabilities, and performance
Classification of sustainability

practices, capabilities, and

sustainability performance
Model \& propositions development

Highlights

- We systematically reviews the past two decades sustainability studies published in the refereed scientific journals

- We use time dimension to classify and understand sustainability benefits 
- We categorized sustainability practices and performances into short- and long-term perspectives for effective managerial decisions

- We propose research propositions relating firm's capability and its implementation of shortand long-term sustainability practices and sustainability performance.

- We draw attention to the future role of organizational capabilities and their interactions with sustainability practices to achieve better performance.

Keywords: sustainability; time dimension; capabilities; balancing

\section{Introduction}

Along with the rapid economic development, countries worldwide are experiencing severe environmental degradation and intense social problems. This has made it imperative that government and business take sustainability issues more seriously. During the past 20 years, the academic world has been witnessing a surge of publications on the topic of sustainability. Attempts have been made to clarify the drivers, activities and performance outcomes of sustainability. However, the empirical studies are scattered randomly in the overall picture of sustainability and there lacks a systematic way of understanding the issue. Thus, by systematically reviewing the current empirical studies on sustainability, this paper summarizes the popular sustainability theories and practices, identifies research gaps and provides possible directions for future research. In the business context, sustainability is defined as “development that meets the needs of a firm's direct and indirect stakeholders (such as shareholders, employees, clients, pressure groups. Communities, etc.), without compromising its ability to meet the needs of future stakeholders" (Dyllick and Hockerts, 2002). A sustainable company thus has the ability to create profit for its shareholders while protecting the environment and improving the lives of all the stakeholders (Savitz and Weber, 2006). Three pillars jointly support the house of sustainability, namely, environmental integrity, economic prosperity and social equity (Bansal, 2005). Sustainability can only be found at the intersection of the three principles (Bansal, 2005). It is the balanced development and harmonious interaction of these three dimensions that ensures a healthy development of the business and the society.

Based on the three-dimensional (economic, environmental and social) perspective, corporate sustainability is also termed as the Triple-bottom-line (3BL) (Elkington, 1998; Gimenez, Sierra 
and Rodon, 2012) or the Triple Ps of business (people, planet and profit) (Bos-Brouwers, 2010). A truly sustainable organization is expected to address the economic, environmental and social requirements simultaneously (Elkington, 1998), which is a highly complex conundrum full of tensions (Hahn et al., 2014). In addition to the three-dimensional perspective, Dyllick and Hockerts (2002) suggest that a two-dimensional perspective consisting of short-term survival and long-term sustainable development is also appropriately applicable to understanding the concept of sustainability. Lozano, Carpenter and Huisingh (2015) even propose that sustainability should be a four-dimensional construct by including the time dimension. Hörisch, Freeman and Schaltegger (2014) acknowledge the necessity for the co-existence of both a short-term and a long-term perspective in a sustainable enterprise. A truly sustainable organization is capable of "addressing short-term as well as long-term problems and to offer companies short-term as well as long-term potentials and opportunities" (Hörisch, Freeman and Schaltegger, 2014). Implementing both shortterm and long-term sustainable practices allows firms to effectively increase short-term earnings, and at the same time, protect the environment and social integrity (Chang and Kuo, 2008).

This paper aims to systematically review the existing sustainability research published in academic journals during the past 20 years. Specifically, it summarizes the frequently used theories in the context of sustainability, identifies sustainability practices, and performance measures. In addition, it makes efforts to integrate the possible effect of organizational capabilities to the sustainability context. The rest of the paper is organized as follows. Section 2 introduces the methodology employed for this review. Section 3 presents extant theories in sustainability studies with respect to external and internal drivers of firms' adoption of sustainability practices from both static and dynamic ways. Section 4 reports the review of existing empirical studies on sustainability, and identifies popular sustainability practices and performance measures. Section 5, based on the results of Section 4, categorizes the sustainability practices and performance measures into shortand long-term based on time dimension, and integrates the concept of capabilities in this context. Section 6 raises the issue of the balance between short- and long-term sustainability. Section 7 gives potential directions for future research and at the end, Section 8 concludes the whole paper.

\section{Research Methodology}

This review paper adapted the method developed by David and Han (2004) as follows: 1) The sample articles used are limited to published scholarly journal articles written in English 
(excluding book chapters and unpublished works) to ensure quality (David and Han, 2004; Newbert, 2007); 2) Only major databases (Scopus, Web of Science, and Google Scholar) used in previous literature review studies in similar fields (Engert, Rauter and Baumgartner, 2016) were used; 3) Empirical sustainability-related studies in the broad area of Management were searched using keywords such as "sustainability" "triple bottom line" "corporate social responsibility" "lean production" "environmental management", "sustainability theories", "resource-based view", "institutional theory", "dynamic capabilities", "stakeholder theory" and "natural resource-based view" through these the databases; 4) The identified articles were then checked for relevance with the current topic. After excluding the irrelevant articles, we categorized the papers based on topics. As a result, 58 papers from 28 journals and containing at least the combination of two of the above keywords were identified using the above criteria. The journals are listed in Table 1.

Table 1: List of journals

\begin{tabular}{|c|l|c|}
\hline No. & \multicolumn{1}{|c|}{ Journal titles } & No. of Papers \\
\hline 1 & International Journal of Operations and Production Management & 2 \\
\hline 2 & International Journal of Production Economics & 11 \\
\hline 3 & Journal of Supply Chain Management & 2 \\
\hline 4 & Production and Operations Management & 10 \\
\hline 5 & Journal of Cleaner Production & 4 \\
\hline 6 & Ecological Economics & 3 \\
\hline 7 & Journal of Business Ethics & 2 \\
\hline 8 & Strategic Management Journal & 1 \\
\hline 9 & Business Ethics: A European Review & 1 \\
\hline 10 & Sustainable Development & 1 \\
\hline 11 & Transportation Research Part E: Logistics and Transportation Review & 1 \\
\hline 12 & Industrial Marketing Management & 3 \\
\hline 13 & Business Strategy and the Environment & 1 \\
\hline 14 & Scandinavian Journal of Management & 1 \\
\hline 15 & Journal of International Management & 2 \\
\hline 16 & Journal of Environmental Management & 1 \\
\hline 17 & European Management Journal & \multicolumn{1}{|c|}{. } \\
\hline & & 1 \\
\hline
\end{tabular}




\begin{tabular}{|r|l|c|}
\hline 18 & Management Decision & 1 \\
\hline 19 & American Journal of Economics & 1 \\
\hline 20 & Journal of Purchasing and Supply Management & 1 \\
\hline 21 & Journal of Business and Industrial Marketing & 1 \\
\hline 22 & Strategic Change & 1 \\
\hline 23 & Accounting Forum & 1 \\
\hline 24 & Technology in Society & 1 \\
\hline 25 & International Journal of Quality and Reliability Management & 1 \\
\hline 26 & International Journal of Production Research & 1 \\
\hline 27 & Journal of Management Studies & 1 \\
\hline 28 & Business Horizons & 1 \\
\hline
\end{tabular}

Using time dimension, we categorized practices, capabilities and performance to achieve shortand long-term sustainability, as shown in Table 2. From a systematic review of the literature, we found that practices in the lean, green and social management systems are among the top sustainability practices.

In addition to these popular sustainability practices, capabilities also emerge as an important topic in sustainability literature. This review also looks at capabilities based on the time dimension, and they are also classified into short- and long-term capabilities.

Similarly, sustainability performance in this review is also divided into short- and long-term sustainability. The measures for sustainability performance are all from the traditional 3BL concept, but with an added dimension of time. Table 2 summarizes the main topics covered in this review.

Table 2: Main topics identified from literature review

\begin{tabular}{|c|c|c|}
\hline Approaches & \multicolumn{2}{|c|}{ Sustainability } \\
\hline $\begin{array}{c}\text { Drivers } \\
\text { classification }\end{array}$ & - External Drivers & - $\quad$ Internal Drivers \\
\hline Drivers & $\begin{array}{ll}\text { - } & \text { Stakeholder theory } \\
\text { - } & \text { Institutional theory }\end{array}$ & $\begin{array}{ll}\text { - } & \text { Resource-based View (RBV) } \\
\text { - } & \text { Natural Resource-based View } \\
& (\mathrm{NRBV})\end{array}$ \\
\hline
\end{tabular}




\begin{tabular}{|c|c|c|}
\hline & & - Capabilities theory \\
\hline $\begin{array}{l}\text { Approaches } \\
\text { classification }\end{array}$ & Short-term Sustainability & Long-term Sustainability \\
\hline Practices & $\begin{array}{ll}\text { - } & \text { Lean } \\
\text { - } & \text { Reactive } \\
& \text { practices } \\
\text { - } & \text { Safety }\end{array}$ & $\begin{array}{ll}\text { - } & \text { Proactive environmental } \\
\text { practices } \\
\text { - }\end{array}$ \\
\hline Capabilities & - Short-term capabilities & - Long-term capabilities \\
\hline Performance & $\begin{array}{l}\text { - Short-term profitability } \\
\text { - }\end{array}$ & $\begin{array}{ll}\text { - } & \text { Long-term financial } \\
\text { - } & \text { Enformance } \\
\text { - } & \text { Social performance }\end{array}$ \\
\hline Balancing & \multicolumn{2}{|c|}{ Short term Vs. Long term - Yinyang Perspective } \\
\hline
\end{tabular}

\section{Sustainability theories}

Existing studies on sustainability rely mainly on two streams of organizational theories. The first includes the stakeholder theory and the institutional theory, which explain firms' adoption of sustainability from an external perspective. In other words, these theories shed light on the external drivers of firms' sustainability strategies. The second stream of sustainability theories, including the Resource-based View (RBV), the Natural Resource-based View (NRBV), and the Dynamic Capabilities View (DCV), are mainly used to explain the internal motivation of firms' movement towards sustainability. In the second stream, while the RBV, the NRBV and the PBV are static in nature, the DCV uses a dynamic perspective to explain firms' sustainability strategies. The following sections present a careful review of these popular sustainability theories and the extent to which they have been used in sustainability-related studies.

\subsection{External drivers of sustainability}

\section{Stakeholder theory}


Stakeholder theory and institutional theory are frequently employed in sustainability research to explain the external drivers of firms' implementation of sustainability strategies from different perspectives. Stakeholder theory proposes that firms survive and make profits by satisfying different stakeholder groups (Clement, 2005). Stakeholders are "persons or groups with legitimate interests in procedural and/or substantive aspects of corporate activity" (Donaldson and Preston, 1995) without whose support the corporation would not exist (Zink, 2007). Generally speaking, stakeholders include investors, employees, suppliers, customers, governments, political groups, trade associations, communities, special interest groups, and competitors, as well as the media (Donaldson and Preston, 1995; Clement, 2005). These stakeholder groups differ in their interest, they have varying, even conflicting requirements, of the firm. Firms thus need to make strategic decisions to appropriately fulfil different stakeholder expectations at different points of time given their limited resources. Stakeholder management is of central importance in the context of sustainability because to achieve sustainable development firms need to respect and satisfy all the stakeholder groups equally and long term (Garvare and Isaksson, 2001; Todorut, 2012; Seuring and Gold, 2013).

Stakeholder pressures are widely proven to be a major driver of corporate sustainability. Clement (2005) believes that by properly responding to stakeholder concerns, firms can actually improve their bottom line. According to Cespedes-Lorente, Burgos-Jimenez and Alvarez-Gil (2003) and Garces-Ayerbe, Rivera-Torres and Murillo-Luna (2012), there is a positive relationship between stakeholder pressure and firms' adoption of environmental management practices. Darnall, Henriques and Sadorsky (2010) provide empirical support for the positive impact of stakeholder pressure on firm environmental proactivity. Indeed, Adebambo et al. (2013) report that stakeholder pressure, legislation and perceived benefits have a direct influence on the implementation of sustainable environmental manufacturing practices and firm performance. Similarly, according to Pun (2006), factors that drive environmentally responsible operations include: government policies and regulations; pressure from consumers; and the life-threatening impact of global ecosystem deterioration. Stakeholder pressure, therefore, plays a crucial role in the formation of corporate change toward sustainability.

\section{Institutional theory}


Different from stakeholder theory, institutional theory explains the way in which external institutional forces influence firms' adoption of an organizational practice (Sarkis, Zhu and Lai, 2011). Dimaggio and Powell (1983) identify three forms of mechanisms through which isomorphic change takes place, namely, coercion, mimesis, and norms. Coercive institutional pressures, which stem from political and legitimate forces, are exerted on a dependent firm by other organizations and by cultural expectations in the society within which the dependent firm exists (Lai, Wong and Cheng, 2006). Simply, coercive pressures come from organizations in power (Sarkis, Zhu and Lai, 2011). Examples of coercive isomorphism include governmental laws and regulations (Sarkis, Zhu and Lai, 2011), and standard operating procedures and rules (Dimaggio and Powell, 1983). Mimetic institutional pressures come mainly from successful peers of the firms. Firms tend to imitate their successful competitors to "replicate their successful paths" (Sarkis, Zhu and Lai, 2011). The core reason for their imitative behavior is "uncertainty" (Dimaggio and Powell, 1983). When a firm faces uncertainty about the environment and the market within which it operates, its goals remain uncertain, even to the firm itself, so that all it can do, at the least expense, is simply learn from others. According to Sarkis, Zhu and Lai (2011), globalization has been facilitating the imitation between firms as it creates opportunities for them to learn from their international counterparts. Normative pressures are believed to come from professionalization (Dimaggio and Powell, 1983; Lai, Wong and Cheng, 2006). Examples of normative pressures include the standards formed on a sector level, or a market level, which force individual companies in this particular sector, or companies operating in this market, to adopt a certain practice.

Institutional theory has been widely applied in the context of sustainability. According to Bansal (2005), institutional factors positively influence firms' adoption of sustainable practices. Similarly, Zhu, Cordeiro and Sarkis (2012) found that both international and domestic coercive, normative and mimetic pressures are forcing Chinese firms to achieve their diverse objectives of sustainability. Similarly, Zhu, Sarkis and Lai (2013) found empirical evidence that in the Chinese context, the adoption of green supply chain management practices by firms are largely driven by institutional factors. 


\subsection{Internal motivations of sustainability}

Theories used to explain the internal motivations of firms' adoption of sustainability practices include the RBV and the NRBV, which are discussed in the following sections in detail. A common feature of these theories is that they are all based on a static perspective. They explain firms' competitive advantage based on practices or resources/capabilities, they do not consider the effect of market dynamism. Following a discussion of these three theories, the DCV will be presented to explain firms' sustainability engagement from a dynamic perspective.

\section{The Resource-based View (RBV)}

As a dominant paradigm in strategic management, the RBV has been increasingly extended to other research fields such as operations management, marketing, and management sub-disciplines, like human resource management and entrepreneurship (Hitt, Xu and Carnes, 2016). The origin of the RBV dates back to Penrose (1959) who argued that a firm's internal growth and external expansion through merger, acquisition and diversification are due to the manner in which its resources are employed (Newbert, 2007). Later, Rubin (1973) and Wernerfelt (1984) proposed that the resources by themselves are of no use; the way they are made useful drives performance growth. Based on these previous studies, Barney (1991) first formalizes the RBV and explains how strategic resources can provide organizations with a competitive advantage. It is believed that when the internal resources of an organization can be leveraged to help guard against all external forces that have the potential to negatively influence the performance, this organization will enjoy a competitive advantage over its competitors (Campbell and Park, 2016). From a RBV point of view, a firm is a bundle of resources and capabilities (Rubin, 1973; Nath, Subramanian and Ramanathan, 2010), and organizations should be evaluated and analysed based on their resources (Schoenherr, 2012). Resources are "stocks of available factors that are owned or controlled by the firm”, including "all assets, capabilities, organizational processes, firm attributes, information, knowledge, etc." (Nath, Subramanian and Ramanathan, 2010; Barney, 1991). They can be categorized into physical capital resources, human capital resources, and organizational capital resources (Barney, 1991). Different resources are believed to come from different sources (Lozano, Carpenter and Huisingh, 2015). While some resources can be bought, others can only be developed over time within the organization (Lozano, Carpenter and Huisingh, 2015). According 
to Barney (1991), since strategic resources are distributed across firms in a heterogeneous manner, a firm will achieve a competitive advantage if it possesses resources which are valuable and rare. If the resources are simultaneously valuable, rare, inimitable and non-substitutable (VRIN), the competitive advantage is believed to be sustained (Barney, 1991). As suggested by Schoenherr (2012), valuable resources help improve the effectiveness and efficiency of the firm and rare resources provide competitive disparity beneficial to the firm. Inimitable resources are those which are difficult for competitors to replicate due to their uniqueness or complexity. If there is no strategic equivalence to a certain resource, then it can be labelled as non-substitutable. VRIN resources are usually tacit or socially complex as they are often skill-based and people-intensive (Menguc and Ozanne, 2005).

The RBV is one of the most widely adopted theoretical lenses in sustainability-related strategic management research. Bansal (2005) justifies the applicability of the RBV in the context of sustainable development with three points. Firstly, it has been well proven that corporate sustainability can affect firm performance. Secondly, investment of financial and/or human resources is required for firms to shift towards sustainability. Thirdly, new opportunities such as international experience, capital management capabilities, and organizational slack can be created through changes in technology, legislation, and market forces from corporate sustainable development. Some researchers use the RBV to explain the relationship between the environmental elements of sustainability and business performance (Darnall, Henriques and Sadorsky, 2008; Schoenherr, 2012; Sambasivan, Bah and Jo-Ann, 2013). Xia, Govindan and Zhu (2015) systematically assessed the barriers to the Chinese automotive industry's implementation of re-manufacturing practices based on the RBV framework. On the other hand, the RBV was used by Falkenberg and Brunsæl (2011) and Torugsa, O'Donohue and Hecker (2012) in an attempt to clarify the effect of CSR on the financial performance of firms. The RBV serves as the optimal theoretical basis for studies on the potential competitive effects of sustainability strategies.

\section{Natural Resource-based View (NRBV)}

Hart (1995) points out that the constraints imposed by the natural environment have been ignored by the RBV and on this basis the Natural Resource-based View (NRBV) was proposed. The NRBV 
argues that business organizations are dependent on, and constrained by, resources offered by the natural environment to prosper and flourish (Wong et al., 2012). Firms need to develop the capability to exploit and preserve natural resources to achieve superior performance (Hart and Dowell, 2011). Environmental considerations thus need to be incorporated into a firm's strategic planning processes, the maintenance of which enhances the development of the firm's capabilities (Chan, 2005). Three key capabilities fulfil this purpose: pollution prevention, product stewardship, and sustainable development (Hart, 1995). Each has a different environmental driving force and is associated with a particular competitive advantage. In general, the NRBV specifies the links between corporate green strategies, green capabilities, and competitive advantage at a firm level, which requires firms to take a long-term, instead of a short-term, focus on immediate profit only to accumulate resources and manage capabilities in making strategic decisions (Lee and Min, 2015).

The NRBV mainly connects with sustainability in terms of the environmental dimension. From the NRBV perspective, the development of the green capabilities motivates firms to shift from the reactive to the proactive end of environmental strategies, in which they develop preventive approaches instead of using end-of-pipe solutions to deal with environmental problems (Fraj, Martınez and Matute, 2013; Li et al., 2016). However, from a sustainability perspective, the NRBV is fragmented because it ignores the social (Klassen and Vereecke, 2012) and the economic dimensions. More importantly, the synergistic effect of a simultaneous implementation of different kinds of sustainability practices on capability development is not captured in the NRBV. Thus, this study aims to extend the NRBV to a sustainability context.

\section{Dynamic Capabilities View (DCV)}

While the RBV, NRBV, and the PBV are based on a static perspective, the DCV has been used to explain sustainability-related issues from a dynamic point of view. According to Barney (1991), a capability is an intangible form of resource. Some researchers tend to separate capabilities from resources from a routine-based perspective (Peng, Schroeder and Shah, 2008; Wu, Melnyk and Flynn, 2010). According to Peng, Schroeder and Shah (2008, p.732), resources are "tangible and intangible firm assets that could be put into productive use". Capabilities, on the other hand, are 
"high-level routines or bundles of routines" which refer to "organizational processes that utilize clusters of resources to achieve desired outcomes" (Peng, Schroeder and Shah, 2008, p.732). The concept of capabilities is further illustrated in the theory of dynamic capabilities (Teece, Pisano and Shuen, 1997).

The DCV was developed from the RBV of the firm. The RBV is criticized as being "static" which neglects the influence of the dynamic market (Eisenhardt and Martin, 2000) in a number of ways. That is, it generally relies on protecting and leveraging existing resources (Russo, 2009), it fails to address how future resources can be created, and how the currently-possessed resources can be refreshed according to the new requirements coming from the changing environments (Ambrosini and Bowman, 2009). According to Carmeli (2004), in the current business environment which is dynamic and highly competitive, the real source of competitive advantage lies in a firm's ability to consistently meet environmental changes, as well as to change the industry structure. The real source of competitive advantage is not the VRIN resources per se, but the firm's capability to constantly update its resources and operational capabilities to keep pace with the changing environment (Cepeda and Vera, 2007).

Teece, Pisano and Shuen (1997) define dynamic capabilities as "the firm's ability to integrate, build, and reconfigure internal and external competencies to address rapidly changing environments". According to Eisenhardt and Martin (2000, p.1107), dynamic capabilities refer to

"a firm's processes that use resources-specifically the processes to integrate, reconfigure, gain and release resources-to match or even create market change. Dynamic capabilities thus are the organizational and strategic routines by which firms achieve new resources configuration as markets emerge, collide, split, evolve and die".

Dynamic capabilities are path-dependent, they are shaped by the decisions made by an organization throughout its history, the assets it holds and its organizational leaning activities (Ambrosini, Bowman and Collier, 2009). 
The DCV has been increasingly applied to the context of sustainability. Russo (2009) explains the impact of ISO 14001 on firm emission performance based on a dynamic capabilities perspective. He found that early adoption of ISO 14001 to be associated with lower emissions; the longer a facility operates ISO 14001, the lower its emissions. In Russo's (2009) empirical study, early adoption of ISO 14001 and the continued use of path dependent learning to strengthen the application are considered as crucial ways to build dynamic capabilities. Similarly, Hofmann, Theyel and Wood (2012) identify a positive relationship between firms' dynamic capabilities (the adoption of advanced technology, experiences with inter-firm relations, and capacity for product innovation) and environmental management practices. Wu, He and Duan's (2012) in-depth case study of the Chinese leading Telecom company, Huawei, found empirical evidence that dynamic capabilities (dynamic scanning, identification, and reconfiguration) facilitate firms' strategic change toward sustainability (which involves the implementation of various sustainable practices). According to Wu et al. (ibid), firms with higher levels of dynamic capabilities are more effective

in detecting stakeholder requirements, seizing sustainability opportunities to meet rapidly changing needs and reconfiguring the existing functional capabilities for corporate sustainability.

\section{Empirical studies on sustainability}

The recent decade has been seeing a tendency in operations/management research to move from the traditional "environmental" or "social" topics to the holistic "sustainability" concepts (Chang and Kuo, 2008; Gimenez, Sierra and Rodon, 2012). Instead of regarding sustainability as simply environmental or social issues, this group of research acknowledge the three dimensions of sustainability. Some studies attempt to clarify the specific practices in each dimension (Delai and Takahashi, 2013; Amini and Bienstock, 2014). Other studies in this category mainly focus on the impact of environmental and social sustainability on economic or overall sustainability, and the findings are mostly consistent. In general, sustainability practices have been found to be positively related with sustainability performance with different levels of strength and time required (Chang and Kuo, 2008; Gimenez, Sierra and Rodon, 2012; Kurapatskie and Darnall, 2013), and firms need to properly balance the economic, environmental and social dimensions of sustainability to maintain the optimal sustainable operations in the context of stiff market competition (Tomsic, Bojnec and Simcic, 2015). Table 3 summarizes emerging studies on sustainability.

Table 3: Summary of emerging sustainability studies 


\begin{tabular}{|c|c|c|}
\hline Source & Relationship Addressed & Main Findings \\
\hline Chang and Kuo, 2008 & Sustainability \& FP & Positive relationship. \\
\hline $\begin{array}{l}\text { Pullman, Maloni and } \\
\text { Carter, 2009 }\end{array}$ & $\begin{array}{l}\text { Environmental and social } \\
\text { sustainability practices \& } \\
\text { performance }\end{array}$ & Positive relationship. \\
\hline $\begin{array}{l}\text { Gimenez, Sierra and } \\
\text { Rodon, 2012 }\end{array}$ & $\begin{array}{l}\text { Green \& 3BL } \\
\text { Social \& 3BL }\end{array}$ & $\begin{array}{l}\text { Internal green practices are } \\
\text { positively related with 3BL } \\
\text { performance while internal social } \\
\text { practices only positively relate } \\
\text { with social and EP. }\end{array}$ \\
\hline $\begin{array}{l}\text { Kurapatskie and Darnall, } \\
2013\end{array}$ & Sustainability \& FP & Positive relationship. \\
\hline Govindan et al., 2014 & 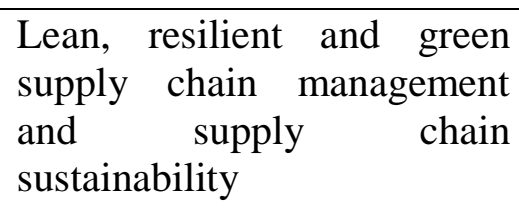 & Positive relationship. \\
\hline Luzzini et al., 2015 & $\begin{array}{l}\text { Sustainability commitment \& } \\
\text { 3BL }\end{array}$ & $\begin{array}{l}\text { Positive relationship due to } \\
\text { collaborative capability. }\end{array}$ \\
\hline
\end{tabular}

Unlike the above-mentioned studies which deal with sustainability problems holistically, others have been found to focus on one or two dimensions. In this category of research, some investigate the impact of lean and green practices on various aspects of firm performance, as well as the relationship between lean and green, others mainly take a long-term perspective toward sustainability, focusing on corporate social practices and performance. To our best knowledge, studies systematically looking at sustainability from a short-term and long-term perspective do not exist.

\subsection{Lean Practices and Performance}

Most studies in this stream focus on the impact of the implementation of lean practices on corporate financial or environmental performance, and the results are inconsistent. A positive relationship between lean practices and firm performance has been identified by Lewis (2000), Yang, Hong and Modi (2011), Hofer, Eroglu and Hofer (2012), among others. Papers in this stream of literature are summarized in Table 4.

Table 4: Summary of lean practices 


\begin{tabular}{|l|l|l|}
\hline \multicolumn{1}{|c|}{ Source } & \multicolumn{1}{|c|}{$\begin{array}{c}\text { Relationship } \\
\text { Addressed }\end{array}$} & \multicolumn{1}{|c|}{ Main Findings } \\
\hline Lewis (2000) & $\begin{array}{l}\text { Lean \& Financial } \\
\text { Performance (FP) }\end{array}$ & $\begin{array}{l}\text { Positive relationship due to enhanced } \\
\text { productivity. }\end{array}$ \\
\hline $\begin{array}{l}\text { King and Lenox } \\
(2001)\end{array}$ & $\begin{array}{l}\text { Lean } \\
\text { Environmental } \\
\text { Performance (EP) }\end{array}$ & Positive relationship. \\
\hline $\begin{array}{l}\text { Fullerton and Wempe } \\
(2009)\end{array}$ & Lean \& FP & $\begin{array}{l}\text { The utilization of non-financial performance } \\
\text { measures (NFP) mediates the relationship } \\
\text { between lean and FP. }\end{array}$ \\
\hline $\begin{array}{l}\text { Yang, Hong and Modi } \\
(2011)\end{array}$ & Lean \& FP \\
\hline $\begin{array}{l}\text { Hofer, Eroglu and } \\
\text { Hofer (2012) }\end{array}$ & Lean \& FP & $\begin{array}{l}\text { The impact of lean production on FP is partially } \\
\text { mediated by inventory leanness. }\end{array}$ \\
\hline $\begin{array}{l}\text { Hajmohammad et al. } \\
(2013)\end{array}$ & Lean \& EP & Positive relationship. \\
\hline $\begin{array}{l}\text { Khanchanapong et al. } \\
(2014)\end{array}$ & $\begin{array}{l}\text { Lean } \\
\text { Operational } \\
\text { Performance (OP) }\end{array}$ & Positive relationship. \\
\hline Chavez et al. (2015) & Lean \& OP & Positive relationship. \\
\hline
\end{tabular}

\subsection{Green Practices and Performance}

Studies in this stream have generated inconsistent findings on the impact of green practices on the financial or environmental performance of the firm. A positive effect of the implementation of various green practices on corporate environmental or financial performance has been identified by Lopez-Gamero, Molina-Azorin and Claver-Cortes (2009), Pullman, Maloni and Carter (2009), Zeng et al. (2010), among others. It is commonly acknowledged that proactive environmental strategies such as the implementation of cleaner production activities will cause extra costs for firms in the short term. In the long run, this negative relationship becomes positive through the mechanisms of enhanced environmental performance and the R\&D efforts fostered by these practices which can generate additional value (Lopez-Gamero, Molina-Azorin and Claver-Cortes, 2009 and 2010; among others). As summarized by Horvathova (2012) and Chang and Kuo (2008), there is a lag in the effect of environmental practices on financial performance, indicating that a win-win situation where financial performance is enhanced by the implementation of green 
practices can be only achieved in the long term. Papers on green practices are presented in Table 5.

Table 5: Summary of green practices

\begin{tabular}{|c|c|c|}
\hline Source & $\begin{array}{c}\text { Relationship } \\
\text { Addressed }\end{array}$ & Main Findings \\
\hline Sroufe (2003) & Green \& OP & Positive relationship. \\
\hline $\begin{array}{l}\text { Pullman, Maloni and } \\
\text { Carter (2009) }\end{array}$ & Green \& EP & Positive relationship. \\
\hline $\begin{array}{l}\text { Lopez-Gamero, } \\
\text { Molina-Azorin and } \\
\text { Claver-Cortes (2009) }\end{array}$ & Green \& EP \& FP & Positive relationship. \\
\hline $\begin{array}{l}\text { Lopez-Gamero, } \\
\text { Molina-Azorin and } \\
\text { Claver-Cortes (2010) }\end{array}$ & $\begin{array}{l}\text { Green \& Competitive } \\
\text { advantage \& FP }\end{array}$ & $\begin{array}{l}\text { Positive relationship due to enhanced cost } \\
\text { and differentiation competitive } \\
\text { advantage. }\end{array}$ \\
\hline Zeng et al. (2010) & Green \& FP & Positive relationship. \\
\hline $\begin{array}{l}\text { Yang, Hong and Modi } \\
\text { (2011) }\end{array}$ & Green \& FP & $\begin{array}{l}\text { The direct impact of environmental } \\
\text { management practices on FP is negative. } \\
\text { However, in the long run, enhance EP } \\
\text { reduces the negative impact. }\end{array}$ \\
\hline $\begin{array}{l}\text { Wagner and } \text { Blom } \\
(2011)\end{array}$ & Green \& FP & Positive relationship. \\
\hline $\begin{array}{l}\text { De Giovanni and Vinzi } \\
\text { (2012) }\end{array}$ & Green \& EP \& FP & Positive relationship. \\
\hline $\begin{array}{l}\begin{array}{l}\text { Lioui } \\
(2012)\end{array} \\
\text { and }\end{array}$ & Green \& FP & $\begin{array}{l}\text { Environmental Corporate Social } \\
\text { Responsibility (ECSR) practices } \\
\text { negatively related with FP. However, in } \\
\text { the long run, this impact becomes positive } \\
\text { because the ECSR activity fosters R\&D } \\
\text { efforts which can generate additional } \\
\text { value for the firm. }\end{array}$ \\
\hline Horvathova (2012) & EP \& FP & $\begin{array}{l}\text { The effect of EP on FP is negative because } \\
\text { EP lags by } 1 \text { year and it becomes positive } \\
\text { for 2-year lag. }\end{array}$ \\
\hline $\begin{array}{l}\text { Lo, Yeung and Cheng } \\
\text { (2012) }\end{array}$ & Green \& FP & $\begin{array}{l}\text { The benefit of the implementation of } \\
\text { green practices can be realized within } 3 \\
\text { years. }\end{array}$ \\
\hline $\begin{array}{l}\text { Hajmohammad et al. } \\
\text { (2013) }\end{array}$ & Green \& EP & Positive relationship. \\
\hline
\end{tabular}




\begin{tabular}{|l|l|l|}
\hline Yang et al. (2013) & Green \& EP \& FP & Positive relationship. \\
\hline $\begin{array}{l}\text { Zhu, Sarkis and Lai } \\
(2013)\end{array}$ & Green \& FP & Positive relationship. \\
\hline $\begin{array}{l}\text { Sambasivan, Bah and } \\
\text { Jo-Ann (2013) }\end{array}$ & Green \& EP \& FP & Positive relationship. \\
\hline $\begin{array}{l}\text { Gotschol, de Giovanni } \\
\text { and Vinzi (2014) }\end{array}$ & Green \& EP \& FP & $\begin{array}{l}\text { Long-term positive relationship due to } \\
\text { enhanced EP. }\end{array}$ \\
\hline $\begin{array}{l}\text { Endrikat, Guenther and } \\
\text { Hoppe (2014) }\end{array}$ & EP \& FP & Positive relationship. \\
\hline
\end{tabular}

\subsection{Social Practices and Performance}

For decades, researchers have been making attempts to clarify the impacts of the adoption of CSR practices on various aspects of firm performance. However, to date, the results have still been mixed. The interest on social practices and firm financial performance dominate this stream of literature. By systematically reviewing 84 empirical research papers, Lu et al. (2014) identified positive, negative and neutral findings on the relationship between corporate social and financial performance. Positive impacts of CSR practices on financial performance were identified by Waddock and Graves (1997), Ruf et al. (2001), Lin, Yang and Liou (2009) and Wagner (2010). Conflicting results were generated by Mahoney and Roberts (2007) and Parast and Adams (2012). Using data from 352 companies, Mahoney and Roberts (2007) found no significant relationship between firm CSP and financial performance (FP). In the context of Iran petroleum industry, according to Parast and Adams (2012), CSR is positively related to firm operational performance but it has no significant impact on firm performance measured by competitive market position and profitability.

Bansal (2005) suggest that time should be taken into consideration when researchers study the corporate social-financial performance. The direct impact of CSR practices on firm financial performance can be negative because of the extra costs incurred. However, in the long run, firms begin to realize the financial benefits brought about by CSR practices through the mechanisms such as improved quality performance and enhanced corporate reputation (Pullman, Maloni and Carter, 2009; Hoejmose, Roehrich and Grosvold, 2014). Table 6 presents the papers on CSR.

Table 6: Summary of CSR studies 


\begin{tabular}{|c|c|c|}
\hline Source & $\begin{array}{l}\text { Relationship } \\
\text { Addressed }\end{array}$ & Main Findings \\
\hline $\begin{array}{l}\text { Waddock and Graves } \\
\text { (1997) }\end{array}$ & CSR and FP & Positive relationship. \\
\hline Ruf et al. (2001) & CSR and FP & $\begin{array}{l}\text { Improved Corporate Social Performance } \\
\text { (CSP) has a positive impact on short-term } \\
\text { CFP and in the long-term, CFP is very } \\
\text { likely to improve with an improved CSP. }\end{array}$ \\
\hline $\begin{array}{l}\text { Mahoney and Roberts } \\
\text { (2007) }\end{array}$ & CSP \& FP & $\begin{array}{l}\text { No significant relationship between firm } \\
\text { CSP and FP. }\end{array}$ \\
\hline $\begin{array}{l}\text { Lin, Yang and Liou } \\
(2009)\end{array}$ & CSR and FP & Positive relationship. \\
\hline Wagner (2010) & CSR and FP & $\begin{array}{l}\text { A positive association between corporate } \\
\text { sustainability performance and FP. }\end{array}$ \\
\hline Parast and Adams (2012) & CSR \& FP & $\begin{array}{l}\text { CSR is positively related to OP but it has } \\
\text { no significant impact on FP measured by } \\
\text { competitive market position and } \\
\text { profitability. }\end{array}$ \\
\hline $\begin{array}{l}\text { Hoejmose, Roehrich and } \\
\text { Grosvold (2014) }\end{array}$ & $\begin{array}{l}\text { Social \& competitive } \\
\text { advantage }\end{array}$ & $\begin{array}{l}\text { Responsible supply chain management } \\
\text { (RSCM) practices enhance firm } \\
\text { reputation. The RSCM-reputation- } \\
\text { competitive advantage link was not } \\
\text { confirmed. }\end{array}$ \\
\hline
\end{tabular}

\section{Short-term and Long-term Sustainability Practices, capabilities, and performance}

\subsection{Short-term and long-term sustainability practices}

The above review suggests that practices in lean, green, and social management systems are popular sustainability practices. Firms easily embrace and adopt some of the practices because the positive effects of these practices can be realized in shorter periods of time compared with other sustainability practices. This is not surprising as the primary objective of businesses is profit maximization for shareholders and short-term profitability is a dominant element of short-term sustainability (Buyukozkan, Kayakutlu and Karakadilar, 2015). In this study, we term such practices as short-term sustainability practices. Nowadays, short-term sustainability is still the top priority for most manufacturers especially those in the developing countries (Laosirihongthong, Adebanjo and Tan, 2012). 
Lean management systems have been well proven to be an important means for firms to achieve short-term profitability. Lean Production, also called Toyota Production System (TPS) or Japanese Management Practices (Bergenwall, Chen and White, 2012), is bundles of practices aimed at reducing and eliminating all forms of wastes and non-value-added activities from firms' manufacturing operations (Yang, Hong and Modi, 2011). These bundles of practices are interrelated, internally consistent and mutually facilitating, including Just-In-Time (JIT), Total Quality Management (TQM), Total Preventive Maintenance (TPM), Human Resource Management (HRM), kanban, etc. (Shah and Ward, 2003; Hajmohammad et al., 2012; Hofer, Eroglu and Hofer, 2012). The ultimate goal of lean production is to increase profitability by systematically minimizing wastes and increasing efficiency (Hofer, Eroglu and Hofer, 2012). Lean was designed to identify and reduce seven forms of wastes, namely, overproduction, waiting, transportation, defects, inappropriate processing, unnecessary inventory and unnecessary motion (Verrier et al., 2014). Lean production has a central focus on the customers, and it starts by understanding what the customers want, how much they want and when they want it (Heizer and Render, 2006, p. 641). By satisfying customers with the appropriate products in the right amount at the exact time, firms become more efficient. Based on the fact that the implementation of lean practices can result in relatively quick benefits for firms, they are classified as short-term sustainability practices in this study.

Another important element of short-term sustainability is the reactive part of green practices and safety issues. According to Endrikat, Guenther and Hoppe (2014), firms can take reactive approach and proactive approach to deal with environmental problems. Reactive firms only implement environmental activities to a minimum level which is required by relevant laws and regulations, and these activities are usually end-of-pipe solutions (Endrikat, Guenther and Hoppe, 2014). It is rational that firms adopt such practices in order to meet short-term requirements. Reactive environmental and safety practices are also classified as short-term sustainability practices in this study.

Unlike short-term sustainability practices, long-term sustainability practices do not result in immediate realization of set objectives and goals. It takes time and efforts for firms to realize the effects of long-term sustainability practices implementation, and the process of realization involves risks (Wang and Bansal, 2012). Ahi and Searcy (2013) believe that the long-term focus is a crucial characteristic of business sustainability. In the context of this study, long-term 
sustainability practices are defined as those practices whose careful and appropriate implementation may result in future prosperity and competitive advantage. It involves the healthy interaction and mutual facilitation among the economic, environmental and social dimensions of sustainability (Dyllick and Hockerts, 2002).

Firms' long-term perspective toward sustainability is best manifested by their adoption of sociallyresponsible practices (Wang and Bansal, 2012). Despite the importance of the human issues, for decades, the social aspect has been largely overlooked (Vallance, Perkins and Dixon, 2011). According to Gimenez, Sierra and Rodon (2012), social sustainability has both internal and external orientations, which commonly covers issues such as equity, diversity, transparency, democratic governance, etc. Socially responsible behavior refers to practices which can at least ensure employees a basic living condition and at the same time do not ruin the natural environment and jeopardize the local community (Campbell, 2007). If a firm does not knowingly adversely affect the interest of its stakeholders and they can rectify any harm immediately after the harm is identified, this firm can be regarded as socially responsible (Campbell, 2007). By taking better care of the stakeholder groups and the society as a whole, it is expected that firms will encounter higher costs and lower profitability (Nidumolu, Prahalad and Rangaswami, 2009). However, this is just a temporary loss and Friedman (1970) claims that the social responsibility of business is to increase its profits, which is more likely to be realized in the long run. As Wang and Bansal (2012) point out, firms especially newly-established firms are encouraged to take a long-term attitude towards social practices because a long-term orientation magnifies the value of the benefits firms get from implementing social practices. However, results of a recent study suggest that only a small minority of Chinese firms implement the long-term sustainability practice in a systematic way (Graafland and Zhang, 2014).

Clarkson (1995) and Shafiq et al. (2014) hold that social responsibility of firms should be assessed from a stakeholder perspective. Among all the stakeholders, employees, customers, suppliers, and the community are closely related with the firm's social actions (Shafiq et al., 2014). Social practices are grouped in the category of long-term sustainability in this study because of their proactive nature, the implementation of which shows the future orientation of the firms.

\subsection{Short-term and long-term Capabilities}


According to Winter (2003), there are mainly two forms of organizational capabilities, namely, operational and dynamic capabilities. Operational capabilities are the "daily routines and processes, including specialized and cross-functional capabilities, that enable a firm to function in a relatively stable business environment" (Gebauer, Johnson and Enquist, 2012). On the other hand, dynamic capabilities refer to the firm's "ability to integrate, build, and reconfigure internal and external competencies to address rapidly changing environments" (Teece, Pisano and Shuen, 1997). With the help of dynamic capabilities, firms are able to compete in the future by constantly renewing their resource base to keep pace with the changing environment. As suggested by the definitions, operational capabilities and dynamic capabilities are different in functions in the context of sustainability.

Operational capabilities are also termed as "ordinary capabilities" because they help firms make a living in the short term by "enabling them to perform an activity on an on-going basis using more or less the same techniques on the same scale to support existing products and services for the same customer population" (Helfat and Winter, 2011; Drnevich and Kriauciunas, 2011). Operational capabilities concern firms' existing products or services, existing business processes, existing customer relationships and existing ways of doing business (Drnevich and Kriauciunas, 2011). Different from resources which are readily observable and operational practices which are standard and transferable, operational capabilities are tacit and imitable. Operational capabilities evolve gradually within a firm and are time and path dependent (Flynn, Wu and Melnyk, 2010). Drawing on resources and operational practices, they generate outcomes consistent with desired results, helping companies develop solutions that make sense (Flynn, Wu and Melnyk, 2010).

Dynamic capabilities are long-term capabilities because they lead the future development of the firms in a constantly changing business environment (Teece, Pisano and Shuen, 1997). They are firms' ability to constantly renew their stock of operational capabilities (Karna, Richter and Riesenkampff, 2015). As dynamic capabilities have been well proven to be more effective in volatile business environment $(\mathrm{Wu}, 2010)$, they exhibit a long-term orientation in aiding firms to cope with uncertainties and risks. Researchers have measured dynamic capabilities in different ways. Wang and Ahmed (2007) see adaptive capability, absorptive capability and innovative capabilities as dynamic capabilities. Li and Liu (2012) believe that dynamic capabilities include strategic sense-making capacity, timely decision-making capacity and change implementation capacity. Lin and Wu (2013) see integration capability, learning capability and reconfiguration 
capability. Nieves and Haller (2014) regard dynamic capabilities as including sensing, learning, integration and coordinating capabilities. Despite the fact that components of dynamic capabilities have been given different labels in existing studies, it is generally accepted that dynamic capabilities rest on three categories of activities, namely, the capability to "sense and shape opportunities and threats", the capability to "seize opportunities" and the capability to "maintain competitiveness through enhancing, combining, protecting, and, when necessary, reconfiguring the business enterprise's intangible and tangible assets" (Teece, 2007).

As short-term (operational) and long-term (dynamic) capabilities differ in functions, firms need both to gain and sustain the competitive advantage (Karna, Richter and Riesenkampff, 2015). In the context of sustainability, firms need to develop short-term capabilities to ensure the operational efficiency and profitability; meanwhile, they cannot afford to ignore the long-term capabilities which could help them avoid certain risks and lead to future prosperity. As suggested by Maletic et al. (2014), corporate sustainability performance can be maximized if firms simultaneously pursue short-term efficiency and long-term discovery.

\subsection{Short-term and Long-term sustainability performance}

So far, studies have only measured sustainability performance from a 3BL perspective. Different indicators have been applied to measure firms' economic, environmental and social performance. For instance, Rodon, Gimenez and Sierra (2012) use unit manufacturing cost, environmental performance, and social reputation as proxies for economic, environmental, and social performance. Chardine-Baumann and Botta-Genoulaz (2014) propose a sustainability performance framework which includes the traditional economic, environmental, and social fields with a number of sub-fields within each. Under economic sustainability, there are reliability, responsiveness, flexibility, financial performance, and quality sub-fields. Environmental sustainability includes environmental management, use of resources, pollution, dangerousness and natural environment. The social dimension consists of work conditions, human rights, societal commitment, customer issues and business practices. 
Based on a time dimension point of view, for economic performance, accounting-based measures such as Return on Assets (ROA) and Return on Sales (ROS) are appropriate to measure short-term financial performance because they indicate "a firm' efficiency at using their assets to generate value", which reflects internal performance rather than external perceptions of performance (Endrikat, Guenther and Hoppe, 2014, p.740). In addition, environmental regulation compliance can be achieved in a short period of time from the adoption of sustainability practices especially environmental practices. Long-term economic performance can be best captured by market-based measures like Tobin's q, which estimates "firms' future prospects", reflecting the notion of external stakeholders. Other indicators including the reduction of emissions, sewage, energy consumption, and the improvement of stakeholder satisfaction and relations are also widely used measures of sustainability performance. All the performance indicators need to be re-organized based on the dynamic dimension of time.

\section{Balancing Sustainability Framework}

Based on the definitions of short-term and long-term sustainability proposed by this review, they need to be properly balanced in order to ensure the short-term efficiency and long-term development at the same time (Eriksson et al., 2014). This review proposes the Chinese traditional philosophy, Yinyang perspective, as a possible theoretical lens to explain the balance of short-and long-term sustainability, especially in the Chinese context.

Figure 1 symbolizes Yinyang thinking. The overall circle made of both black and white represents everything in the world and the black half is "Yin" and the white half "Yang". Yin and Yang are two opposite cosmic energies with Yin being female in nature and Yang male (Fang, 2011). Examples of Yin include women, the moon, night, weakness, darkness and softness, etc. On the contrary, men, the sun, day, strength, brightness and hardness belong to Yang energies. There is a black dot in the white area and a white dot in the black area, meaning that each of them exists in the other and they both coexist in everything in the world. The curvy line between Yin and Yang indicates that there is no absolute separation between them. The curve shows a dynamic feel, meaning that Yin and Yang keep changing to the form of each other (Fang, 2011). 


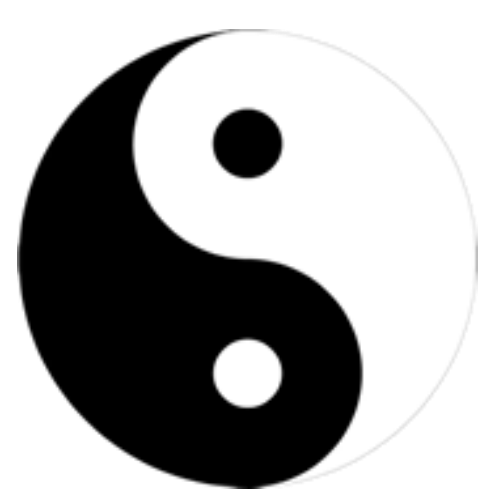

Figure 1 Yinyang Symbol

The Yinyang perspective is applicable to the short- and long-term sustainability context. Shortand long-term sustainability can be resembled by Yang and Yin because they are seemingly conflicting but in nature, they depend on the other and keep changing to the form of the other. On the one hand, an over emphasis on the short-term sustainability harms long-term sustainability because most of the limited resources have to go to the money-making activities. Similarly, if a for-profit organization puts too much attention on long-term sustainability, their short-term profitability can be severely harmed. On the other hand, short-term sustainability practices, if properly implemented, can have profound long-term benefits in addition to the constant short-term benefits. Long-term sustainability practices can also bring firms with unexpected benefits which can facilitate the function of short-term sustainability. However, how firms should balance shortand long-term sustainability at different development stages and in different business environment to maximize short-term efficiency and future prosperity remains a big challenge for firms. We thus propose that Yinyang perspective could be a theoretical lens for the explanation of the balancing problem in China.

Based on the systematic review of literature, we propose the following framework (Fig. 2) for future test.

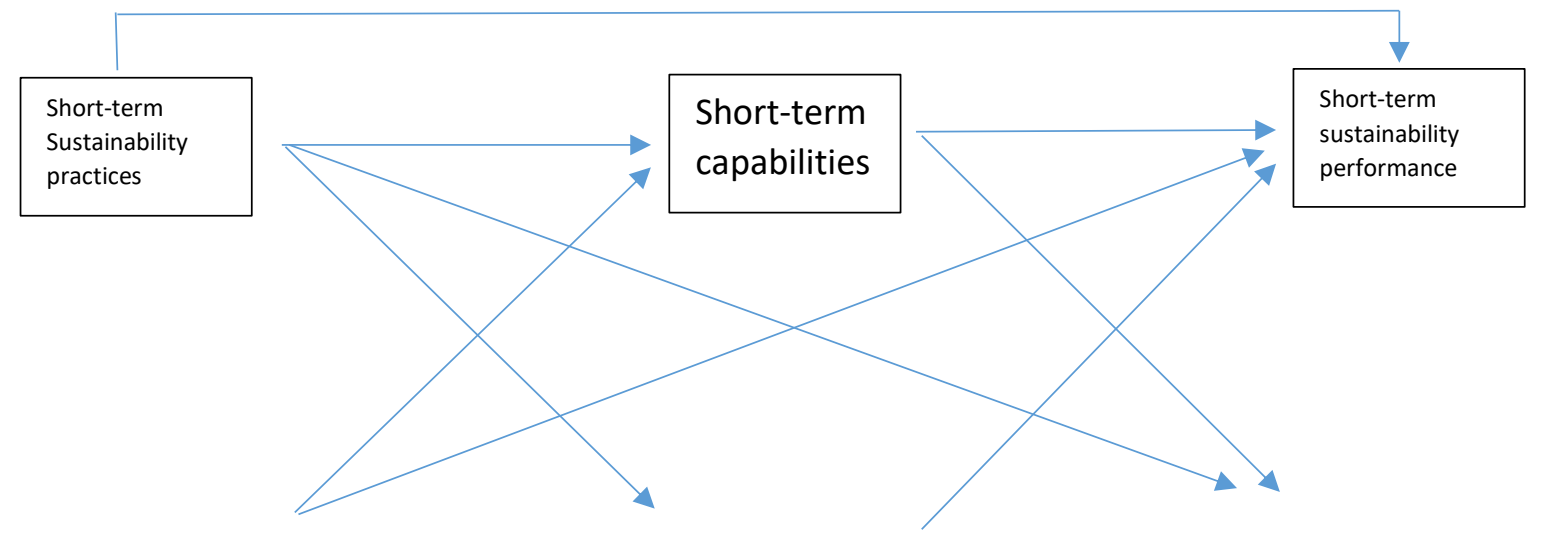




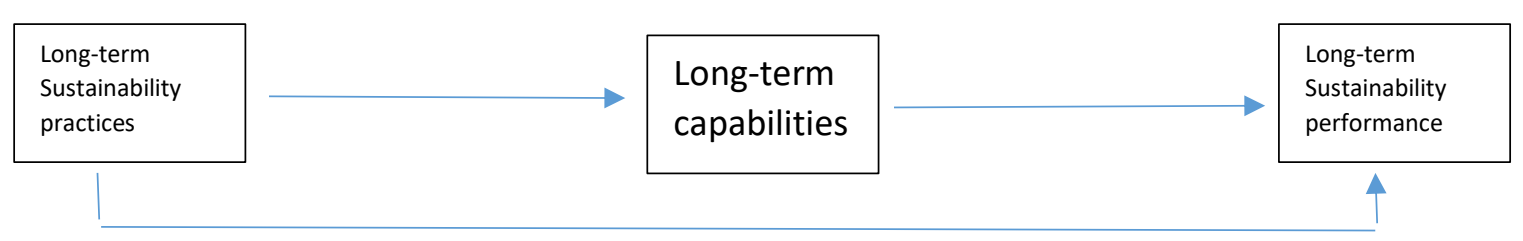

Figure 2 The Research Framework

Based on the research framework developed above, we propose the following research propositions:

P1: The implementation of short-term sustainability practices is positively related with the improvement short-term sustainability performance.

P2: The implementation of short-term sustainability practices is positively related with the improvement of long-term sustainability performance.

P3: The implementation of long-term sustainability practices is positively related with the improvement of short-term sustainability performance.

P4: The implementation of long-term sustainability practices is positively related with the improvement of long-term sustainability performance.

P5: Short-term capabilities mediate the relationships between: a) short-term sustainability practices and short-term sustainability performance; b) short-term sustainability practices and long-term sustainability performance; c) long-term sustainability practices and short-term sustainability performance; d) long-term sustainability practices and long-term sustainability performance.

P6: Long-term capabilities mediates the relationships between: a) short-term sustainability practices and short-term sustainability performance; b) short-term sustainability practices and long-term sustainability performance; c) long-term sustainability practices and short-term sustainability performance; d) long-term sustainability practices and long-term sustainability performance.

\section{Discussions and Future Research Directions}

A systematic review of the literature suggests important research gaps. Although sustainability research is growing rapidly in different research fields, there is a lack of a strong theoretical base 
for such research in strategic and operations management. Researchers either rely on the RBV and NRBV to rationalize firms' adoption of sustainable strategies from a single environmental or social perspective (Lee and Min, 2015), or take a more reactive approach to explain firms' movement toward sustainability from a stakeholder or institutional perspective (Sarkis, Zhu and Lai, 2011; Adebambo et al., 2013). Bansal (2005), among the earliest, attempts to combine the RBV and the institutional theory to explain firms' sustainable development. She found empirical evidence that both resource-based and institutional factors influenced the sustainable development of Canadian oil and gas, mining and forestry firms. As the current study well acknowledges the influence of antecedents of firms' implementation of sustainable practices, it focuses mainly on the internal motivations of firms' sustainable practices. In other words, instead of explaining the factors that forces firms to be sustainable, this study attempts to clarify what firms can get from being sustainable. This review builds on the central argument of the stakeholder theory, the institutional theory, the RBV and the NRBV, explaining firms' strategic actions in the context of sustainability from which they maintain short-term existence without compromising the long-term sustainable development.

Existing empirical studies on sustainability failed to capture a holistic picture. While some research focus on the relationship between elements of short-term practices and performance, others only take the long-term aspect of sustainability. To the best of our knowledge, no study has taken both aspects into consideration. This review bridges this gap by incorporating both short-term and longterm practices and investigate their impact on different aspects of sustainability performance.

Capability research is emerging in strategic management field in recent years. Though the understanding of the concept itself is advancing, their role and contribution remain as a blackbox as there are insufficient theoretical and empirical studies on capabilities (Drnevich and Kriauciunas, 2011). This study empirically tests the roles operational and dynamic capabilities play in the context of short-term and long-term sustainability contexts, attempting to clarify their unique roles in promoting corporate sustainable development.

This study suggests some possible directions for future research. Firstly, given the importance and current absence of the time dimension in the concept of sustainability, later studies are encouraged to distinguish short-term sustainability practices from their long-term counterparts. More importantly, the balancing of short- and long-term sustainability needs further investigation. So 
far, there is no systematic explanation from the theoretical lens of how firms can best balance short- and long-term sustainability to ensure short-term efficiency and long-term prosperity. Researchers are encouraged to use different indigenous theories such as Yinyang in China to lay a theoretical base for the balance issues. Secondly, capabilities as an importance source of competitive advantage cannot be overlooked in sustainability research. The movement towards sustainability is a learning process for all firms, during which knowledge is accumulated and capabilities nurtured. Capabilities then interact with sustainability practices for better sustainability performance.

\section{Conclusion}

This paper thoroughly reviews previous studies for two decades in the areas of sustainability with respect to business context. It suggests that most of the existing sustainability research has taken the traditional 3BL perspective, with the identification of lean, green, and social practices as important sustainability practices. Based on the review, this paper attempts to raise the issue of the time dimension in the concept of sustainability by categorizing popular sustainability practices into short-term and long-term ones, and offers views on how to balance short- and long-term sustainability as a priority for future research. Though important, the time dimension has been largely overlooked in existing sustainability research, which may result in wrong decisions by firms on how to balance them at different points of time. Thus, a time dimension is needed when firms are designing and implementing sustainability strategies. In addition to the effects of the sustainability practices, the time length required for the desired effects to be realized is also needed to be considered.

In addition to the time dimension of sustainability, this paper attempts to draw future attention on the role of organizational capabilities and their interactions with sustainability practices to achieve better performance. Short-term (operational) and long-term (dynamic) capabilities have been identified as important mediators in the relationship between short-/long-term sustainability practices and short-/long-term sustainability performance. Based on existing literature and gaps identified, this study proposes a two-dimensional three-level sustainability framework incorporating popular sustainability practices, key organizational capabilities and sustainability performance, and suggests possible directions for future research. 


\section{Acknowledgements}

The authors would like to thank the Ningbo Science and Technology Bureau, under the Innovation Team Project (Grant No. 2011B1006), for sponsoring this research.

\section{References}

Adebambo, H. O., Abdulkadir, R. I., Mat, N. K. N., Alkafaagi, A. A. J., Kanaan, A. G. J., 2013. Drivers of Sustainable Environmental Manufacturing Practices and Financial Performance among Food and Beverages Companies in Malaysia. American Journal of Economics, 3 (2), 127-131.

Ahi, P., Searcy, C., 2013. A comparative literature analysis of definitions for green and sustainable supply chain management. Journal of Cleaner Production, 52, 329-341.

Ahmed, M. U., Kristal, M. M., Pagell, M., 2014. Impact of operational and marketing capabilities on firm performance: evidence from economic growth and downturns. Int. J. Production Economics, 154, 59-71.

Alsmadi, M., Almadi, A., Jerisat, R., 2012. A Comparative Analysis of Lean Practices and Performance in the UK Manufacturing and Service Sector Firms. Total Quality Management \& Business Excellence, 23 (3-4), 381-396.

Ambrosini, V., Bowman, C., 2009. What are dynamic capabilities and are they a useful construct in strategic management? International Journal of Management Reviews, 11 (1), 29-49.

Ambrosini, V., Bowman, C., Collier, N., 2009. Dynamic capabilities: an exploration of how firms renew their resource base. British Journal of Management, 20, s9-s24.

Amini, A., Bienstock, C. C., 2014. Corporate sustainability: an integrative definition and framework to evaluate corporate practice and guide academic research. Journal of Cleaner Production, 76, 12-19.

Bansal, P., 2005. Evolving Sustainability: A Longitudinal Study of Corporate Sustainable Development. Strategic Management Journal, 26, 197-218.

Barney, J., 1991. Firm Resources and Sustained Competitive Advantage. Journal of Management, 17 (1), 99-120. 
Barrales-Molina, V., Bustinza, O. F., Gutierrez-Gutierrez, L. J., 2013. Explaining the causes and effects of dynamic capabilities generation: a multiple-indicator multiple-cause modelling approach. British Journal of Management, 24, 571-591.

Bergenwall, A., Chen, C., White, R. E., 2012. TPS's Process Design in American Automotive Plants and its Effects on the Triple Bottom Line and Sustainability. Int. J. Production Economics, $140,374-384$.

Bhasin, S., 2012. Performance of Lean in Large Organizations. Journal of Manufacturing Systems, 31, 349-357.

Bos-Brouwers, H. E. J., 2010. Corporate Sustainability and Innovation in SMEs: Evidence of Themes and Activities in Practice. Business Strategy and the Environment, 19, 417-435.

Buyukozkan, G., Kayakutlu, G., Karakadilar, I. S., 2015. Assessment of lean manufacturing effect on business performance using Bayesian Belief Networks. Expert Systems with Applications, 42, 6539-6551.

Calza, F., Profumo, G., Tutore, I., 2014. Corporate ownership and environmental proactivity. Business Strategy and the Environment, DOI: 10.1002/bse.

Campbell, J. L., 2007. Why Would Corporations Behave in Socially Responsible Ways? An Institutional Theory of Corporate Social Responsibility. Academy of Management Review, 32 (3), 946-967.

Carmeli, A., 2004. Assessing core intangible resources. European Management Journal, 22 (1), $110-122$.

Carmeli, A., Tishler, A., 2004. Resources, Capabilities and the Performance of Industrial Firms: A Multivariate Analysis. Managerial and Decision Economics, 25, 299-315.

Carroll, A. B., 1979. A Three-dimensional Conceptual Model of Corporate Performance. Academy of Management Review, 4(1), 497-505.

Cepeda, G., Vera, D., 2007. Dynamic Capabilities and Operational Capabilities: A Knowledge Management Perspective. Journal of Business Research, 60, 426-437. 
Cespedes-Lorente, J., Burgos-Jimenez, J., Alvarez-Gil, M. J., 2003. Stakeholders' Environmental Influence. An Empirical Analysis in the Spanish Hotel Industry. Scandinavian Journal of Management, 19, 333-358.

Chan, R. Y. K., 2005. Does the Natural-Resource-Based View of the Firm Apply in an Emerging Economy? A Survey of Foreign Invested Enterprises in China. Journal of Management Studies, $42(3), 625-672$.

Chang, D., Kuo, L. R., 2008. The Effects of Sustainable Development on Firms' Financial Performance - An Empirical Approach. Sustainable Development, 16, 365-380.

Chavez, R., Yu, W., Jacobs, M., Fynes, B., Wiengarten, F., Lecuna, A., 2015. Internal lean practices and performance: the role of technological turbulence. Int, J. Production Economics, 160, 157-171.

Chi, C. G., Gursoy, D., 2009. Employee satisfaction, customer satisfaction, and financial performance: an empirical examination. International Journal of Hospitality Management, 28 (2009), 245-253.

Chin, T. A., Hamid, A. B. A., Raslic, A., Heng, L. H., 2013. The impact of supply chain integration on operational capability in Malaysian manufacturers. Procedia - Social and Behavioral Sciences, 130, 257-265.

Clarkson, M. B. E., 1995. A stakeholder framework for analyzing and evaluating corporate social performance. Academy of Management Review, 20 (1), 92-117.

Clement, R. W., 2005. The Lessons from Stakeholder Theory for US Business Leaders. Business Horizons, 48, 255-264.

Cramer, J., 1998. Environmental management: from "fit" to "stretch". Business Strategy and the Environment, 7,. 162-172.

Darnall, N., Henriques, I., Sadorsky, P., 2008. Do environmental management systems improve business performance in an international setting? Journal of International Management, 14, 364376.

Darnall, N., Henriques, I., Sadorsky, P., 2010. Adopting Proactive Environmental Strategy: The Influence of Stakeholders and Firm Size. Journal of Management Studies, 47 (6), 1072-1094. 
David, R. J., Han, S-K., 2004. A systematic assessment of the empirical support for transaction cost economics. Strategic Management Journal, 25, 39-58.

De Giovanni, P., Vinzi, V. E., 2012. Covariance versus component-based estimations of performance in green supply chain management. Int. J. Production Economics, 135, 907-916.

Delai, I., Takahashi, S., 2013. Corporate sustainability in emerging markets: insights from the practices reported by the Brazilian retailers. Journal of Cleaner Production, 47, 211-221.

Dimaggio, P. J., Powell, W. W., 1983. The Iron Cage Revisited: Institutional Isomorphism and Collective Rationality in Organizational Fields. American Sociological Review, 48 (2), 147-160.

Donaldson, T., Preston, L. E., 1995. The Stakeholder Theory of the Corporation: Concepts, Evidence, and Implications. Academy and Management Review, 20 (1), 65-91.

Drnevich, P. L., Kriauciunas, A. P., 2011. Clarifying the Conditions and Limits of the Contributions of Ordinary and Dynamic Capabilities to Relative Firm Performance. Strategic Management Journal, 32, 254-279.

Dues, C. M., Tan, K. H., Lim, M., 2013. Green as the new lean: how to use lean practices as a catalyst to greening your supply chain. Journal of Cleaner Production, 40,93-100.

Dyllick, T., Hockerts, K., 2002. Beyond the Business Case for Corporate Sustainability. Business Strategy and the Environment, 11, 130-141.

Eisenhardt, K. M., Martin, J. A., 2000. Dynamic capabilities: what are they? Strategic Management Journal, 21, 1105-1121.

Elkington, J., 1998. Cannibals with Forks: the triple-bottom-line of the $21^{\text {st }}$ century. New Society Publishers, Stoney Creek.

Endrikat, J., Guenther, E., Hoppe, H., 2014. Making Sense of Conflicting Empirical Findings: A Meta-analytic Review of the Relationship between Corporate Environmental and Financial Performance. European Management Journal, 32 (5), 735-751.

Engert, S., Rauter, R., Baumgartner, R. J., 2016. Exploring the integration of corporate sustainability into strategic management: a literature review. Journal of Cleaner Production, 112, 2833-2850. 
Eriksson, P. E., Olander, S., Szentes, H., Widen, K., 2014. Managing short-term efficiency and long-term development through industrialized construction. Construction Management and Economics, 32, 97-108.

Ethiraj, S. K., Kale, P., Krishnan, M. S., Singh, J. V., 2005. Where do capabilities come from and how do they matter? A study in the software services industry. Strategic Management Journal, 26, 25-45.

Falkenberg, J., Brunsæl, P., 2011. Corporate social responsibility: a strategic advantage or a strategic necessity? Journal of Business Ethics, 99, 9-16.

Fang, T., 2011. Yin Yang: A New Perspective on Culture. Management and Organization Review, $8(1), 25-50$.

Fernández-Muñiz, B., Montes-Peón, J. M., Vázquez-Ordás, C. J., 2009. Relation between occupational safety management and firm performance. Safety Science, 47, 980-991.

Flynn, B. B., Wu, S. J., Melnyk, S., 2010. Operational capabilities: hidden in plain view. Business Horizons, 53, 247-256.

Fraj, E., Martinez, E., Matute, F., 2013. Green marketing in B2B organizations: an empirical analysis from the natural-resource-based view of the firm. Journal of Business \& Industrial Marketing, 28 (5), 396-410.

Friedman, M., 1970. The Social Responsibility of Business is to Increase its Profits. New York Times Magazine, September 13.

Fullerton, R. R., Wempe, W. F., 2009. Lean manufacturing, non-financial performance measures, and financial performance. International Journal of Operations \& Production Management, 29 (3), 214-240.

Fuzi, N. M., Desa, A. F. N. C., Hibadullah, S. N., Zamri, I. M., Habidin, N. F., 2012. Corporate social responsibility practices (CSR) and CSR performance in Malaysian automotive industry. International Journal of Accounting and Financial Reporting, 2 (2), 268-277.

Galbreath, J., 2005. Which resources matter the most to firm success? An exploratory study of resource-based theory. Technovation, 25, 979-987. 
Galeazzo, A., Furlan, A., Vinelli, A., 2014. Lean and green in action: interdependencies and performance of pollution prevention projects. Journal of Cleaner Production, 85, 191-200.

Garces-Ayerbe, C., Rivera-Torres, P., Murillo-Luna, J. L., 2012. Stakeholder Pressure and Environmental Proactivity: Moderating Effect of Competitive Advantage Expectations. Management Decision, 50 (2), 189-206.

Garvare, R., Isaksson, R., 2001. Sustainable Development: Extending the Scope of Business Excellence Models. Measuring Business Excellence, 5 (3), 11-15.

Garza-Reyes, J. A., 2015. Lean and green - a systematic review of the state of the art literature. Journal of Cleaner Production, 102, 18-29.

Gebauer, H., 2011. Exploring the contribution of management innovation to the evolution of dynamic capabilities. Industrial Marketing Management, 40, 1238-1250.

Gimenez, C., Sierra, V., Rodon, J., 2012. Sustainable Operations: their impact on the triple bottom line. Int. J. Production Economics, 140, 149-159.

Gotschol, A., De Giovanni, P., Vinzi, V. E., 2014. Is Environmental Management an Economically Sustainable Business? Journal of Environmental Management, 144, 73-82.

Govindan, K., Azevedo, S. G., Carvalho, H., Cruz-Machado, V., 2014. Impact of supply chain management practices on sustainability. Journal of Cleaner Production, 85, 212-225.

Graafland, J., Zhang, L., 2014. Corporate social responsibility in China: implementation and challenges. Business Ethics: A European Review, 23 (1), 34-49.

Hahn, T., Pinkse, J., Preuss, L., Figge, F., 2014. Tensions in corporate sustainability: towards an integrative framework. Journal of Business Ethics, DOI: 10.1007/s10551-014-2047-5.

Hajmohammad, S., Vachon, S., Klassen, R. D., Gavronski, I., 2013. Lean Management and Supply Management: Their Role in Green Practices and performance. Journal of Cleaner Production, 39, 312-320.

Hami, N., Muhamad, M. R., Ebrahim, Z., 2015. The impact of sustainable manufacturing practices and innovation performance on economic sustainability. Procedia CIRP, 26, 190-195.

Hart, S. L., 1995. A Natural-Resource-Based View of the Firm. Academy of Management Review, 20 (4), 986-1014. 
Hart, S. L., Dowell, G., 2011. A natural resource based view of the firm: fifteen years after. Journal of Management, 37 (5), 1464-1479.

Heizer, J., Render, B., 2006. Operations Management. 8th ed. Pearson Prentice Hall. Upper Saddle River: the US.

Helfat, C. E., 1997. Know-how and asset complementarity and dynamic capability accumulation: the case of R\&D. Strategic Management Journal, 18 (5), 339-360.

Hoejmose, S. U., Roehrich. J. K., Grosvold, J., 2014. Is Doing More Doing Better? The Relationship between Responsible Supply Chain Management and Corporate Reputation. Industrial Marketing Management, 43, 77-90.

Hofer, C., Eroglu, C., Hofer, A. R., 2012. The Effect of Lean Production on Financial Performance: the Mediating Role of Inventory Leanness. International Journal of Production Economics, 138 (2), 242-253.

Hofmann, K. H., Theyel, G., Wood, C. H., 2012. Identifying Firm Capabilities as Drivers of Environmental Management and Sustainability Practices - Evidence from Small and Mediumsized Manufacturers. Business Strategy and the Environment, 21, 530-545.

Hörisch, J., Freeman, R. E., Schaltegger, S., 2014. Applying Stakeholder Theory in Sustainability Management: Links, Similarities, Dissimilarities, and a Conceptual Framework. Organization \& Environment, 27 (4), 328-346.

Horvathova, E., 2012. The Impact of Environmental Performance on Firm Performance: shortterm Costs and Long-term Benefits? Ecological Economics, 84, 91-97.

Jabbour, C. J. C., de Sousa Jabbour, A. B. L., Govindan, K., Teixeira, A. A., de Souza Freitas, W. R., 2013. Environmental management and operational performance in automotive companies in Brazil: the role of human resource management and lean manufacturing. Journal of Cleaner Production, 47, 129-140.

Johnson, W. H. A., Filippini, R., 2013. Integration Capabilities as Mediator of Product Development Practices - Performance. Journal of Engineering and Technology Management, 30, 95-111. 
Karna, A., Richter, A., Riesenkampff, E., 2015. Revisiting the Role of the Environment in the Capabilities - Financial Performance Relationship: A Meta-analysis. Strategic Management Journal, DOI: 10.1002/smj.2379.

Khanchanapong, T., Prajogo, D., Sohal, A. S., Cooper, B. K., Yeung, A. C. L., Cheng, T. C. E., 2014. The unique and complementary effects of manufacturing technologies and lean practices on manufacturing operational performance. Int. J. Production Economics, 153, 191-203.

King, A. A., Lenox, M. J., 2001. Lean and green? An empirical examination of the relationship between lean production and environmental performance. Production and Operations Management, 10 (3), 244-256.

Kitchen Jr, D. J., Hult, G. T. M., 2007. Bridging Organization Theory and Supply Chain Management: the Case of Best Value Supply Chains. Journal of Operations Management, 25, 573580.

Klassen, R. D., Vereecke, A., 2012. Social issues in supply chains: capabilities link responsibility, risk (opportunity), and performance. Int. J. Production Economics, 140, 103-115.

Kurapatskie, B., Darnall, N., 2013. Which corporate sustainability activities are associated with greater financial payoffs? Business Strategy and the Environment, 22, 49-61.

Laosirihongthong, T., Adebanjo, D., Tan, K. C., 2012. Green supply chain management practices and performance. Industrial Management \& Data Systems, 113 (8), 1088-1109.

Lee, K-H., Min, B., 2015. Green R\&D for Eco-innovation and Its Impact on Carbon Emissions and Firm Performance. Journal of Cleaner Production, 1-9.

Lee, P. K. C., Lau, A. K. W., Cheng, T. C. E., 2013. Employee rights protection and financial performance. Journal of Business Research, 66, 1861-1869.

Lewis, M. A., 2000. Lean Production and Sustainable Competitive Advantage. International Journal of Operations \& Production Management, 20 (8), 959-978.

Li, D., Liu, J., 2012. Dynamic capabilities, environmental dynamism, and competitive advantage: evidence from China. Journal of Business Research, in press. 
Li, S., Jayaraman, V., Paulraj, A., Shang, K., 2016. Proactive environmental strategies and performance: role of green supply chain processes and green product design in the Chinese hightech industry. International Journal of Production Research, 54 (7), 2136-2151.

Lin, C. H., Yang, H. L., Liou, D. Y., 2009. The Impact of Corporate Social Responsibility on Financial Performance: Evidence from Business in Taiwan. Technology in Society, 31, 56-63.

Lin, Y., Wu, L., 2013. Exploring the Role of Dynamic Capabilities in Firm Performance under the Resource-based View Framework. Journal of Business Research, 67 (3), 407-413.

Lioui, A., Sharma, Z., 2012. Environmental Corporate Social Responsibility and Financial Performance: Disentangling Direct and Indirect Effects. Ecological Economics, 78, 100-111.

Lo, C. K. Y., Yeung, A. C. L., Cheng, T. C. E., 2012. The Impact of Environmental Management Systems on Financial Performance in Fashion and Textiles Industries. Int. J. Production Economics, 135, 561-567.

Lopez-Gamero, M. D., Molina, J. F., Claver-Cortes, E., 2009. The Whole Relationship between Environmental Variables and Firm Performance: Competitive Advantage and Firm Resources as Mediator Variables. Journal of Environmental Management, 90, 3110-3121.

Lopez-Gamero, M. D., Molina, J. F., Claver-Cortes, E., 2010. The potential of environmental regulation to change managerial perception, environmental management, competitiveness and financial performance. Journal of Cleaner Production, 18, 963-974.

Lozano, R., Carpenter, A., Huisingh, D., 2015. A review of 'theories of the firm' and their contributions to corporate sustainability. Journal of Cleaner Production, 106, 430-442.

Lu, W., Chau, K. W., Wang, H., Pan, W., 2014. A Decade's Debate on the Nexus between Corporate Social and Corporate Financial Performance: a Critical Review of Empirical Studies 2002-2011. Journal of Cleaner Production, 79, 195-206.

Luzzini, D., Brandon-Jones, E., Brandon-Jones, A., Spina, G., 2015. From sustainability commitment to performance: the role of intra- and inter-firm collaborative capabilities in the upstream supply chain. Int. J. Production Economics, 165 (C), 51-63.

Mahoney, L., Roberts, R. W., 2007. Corporate Social Performance, Financial Performance and Institutional Ownership in Canadian Firms. Accounting Forum, 31, 233-253. 
Maletic, M., Maletic, D., Dahlgaard, J. J., Dahlgaard-Park, S. M., Gomiscek, B., 2014. Sustainability Exploration and Sustainability Exploitation: from a Literature Review towards a Conceptual Framework. Journal of Cleaner Production, 79, 182-194.

Maranto-Vargas, D., Rangel, R. G., 2007. Development of Internal Resources and Capabilities as Sources of Differentiation of SME under Increased Global Competition: A Field Study in Mexico. Technological Forcasting \& Social Change, 74, 90-99.

Menguc, B., Ozanne, L. K., 2005. Challenges of the "green imperative": a natural resource-based approach to the environmental orientation - business performance relationship. Journal of Business Research, 58, 430-438.

Nath, P., Subramanian, N., Ramanathan, R., 2010. The Impact of Marketing Capability, Operations Capability and Diversification Strategy on Performance: A Resource-based View. Industrial Marketing Management, 39, 317-329.

Ng, R., Low, J. S. C., Song, B., 2015. Integrating and implementing lean and green practices based on proposition of Carbon-value efficiency metric. Journal of Cleaner Production, 95, 242-255.

Nidumolu, R., Prahalad, C. K., Rangaswami, M. R., 2009. Why Sustainability is now the Key Driver of Innovation? Harvard Business Review, May, 57-64.

Nieves, J., Haller, S., 2014. Building Dynamic Capabilities through Knowledge Resources. Tourism Management, 40, 224-232.

Parast, M. M., Adams, S. G., 2012. Corporate Social Responsibility, Benchmarking, and Organizational Performance in the Petroleum Industry: A Quality Management Perspective. Int. J. Production Economics, 139, 447-458.

Pavlou, P. A., El Sawy, O. A., 2011. Understanding the Elusive Black Box of Dynamic Capabilities. Decision Sciences, 42 (1), 239-273.

Peng, D. X., Schroeder, R. G., Shah, R., 2008. Linking Routines to Operations Capabilities: A New Perspective. Journal of Operations Management, 26, 730-748.

Piening, E. P., Salge, T. O., 2015. Understanding the antecedents, contingencies, and performance implications of process innovation: a dynamic capabilities perspective. J Prod Innov Manag, 32 (1), 80-97. 
Pullman, M. E., Maloni, M. J., Carter, C. R., 2009. Food for Thought: Social versus Environmental Sustainability Practices and Performance Outcomes. Journal of Supply Chain Management, 45 (4), 38-54.

Pun, K. F., 2006. Determinants of Environmentally Responsible Operations: A review. International Journal of Quality \& Reliability Management, 23 (3), 279-297.

Ruf, B. M., Muralidhar, K., Brown, R. M., Janney, J. J., Paul, K., 2001. An Empirical Investigation of the Relationship between Change in Corporate Social Performance and Financial Performance: A Stakeholder Theory Perspective. Journal of Business Ethics, 32, 143-156.

Russo, M. V., 2007. Explaining the impact of ISO 14001 on emission performance: a dynamic capabilities perspective on process and learning. Business Strategy and the Environment, 18, 307319 .

Sakis, J., Zhu, Q., Lai, K., 2011. An Organizational Theoretic Review of Green Supply Chain Management Literature. Int. J. Production Economics, 130, 1-15.

Sambasivan, M., Bah, S., Jo-Ann, 2013. Making the Case for Operating "Green": Impact of Environmental Proactivity on Multiple Performance Outcomes of Malaysian Firms. Journal of Cleaner Production, 42, 69-82.

Savitz, A. W., Weber, K., 2006. The Triple Bottom Line. Jossey-Bass, San Francisco, CA.

Schilke, O., 2014. On the contingent value of dynamic capabilities for competitive advantage: the nonlinear moderating effect of environmental dynamism. Strategic Management Journal, 35, 179203.

Schoenherr, T., 2012. The Role of Environmental Management in Sustainable Business Development: A multi-country Investigation. Int. J. Production Economics, 140 (1), 116-128.

Seuring, S., Gold, S., 2013. Sustainability Management beyond Corporate Boundaries: from Stakeholders to Performance. Journal of Cleaner Production, 56, 1-6.

Shafiq, A., Klassen, R. D., Johnson, F., Awaysheh, A., 2014. Socially responsible practices: an exploratory study on scale development using stakeholder theory. Decision Sciences, 45 (4), 683716. 
Shah, R., Ward, P. T., 2003. Lean Manufacturing: context, practice bundles, and performance. Journal of Operations Management, 21, 129-149.

Sharma, S., Vredenburg, H., 1998. Proactive corporate environmental strategy and the development of competitive valuable organizational capabilities. Strategic Management Journal, 19, 729-752.

Shou, Z., Chen, J., Zhu, W., Yang, L., 2014. Firm capability and performance in China: the moderating role of guanxi and institutional forces in domestic and foreign contexts. Journal of Business Research, 67, 77-82.

Sroufe, R., 2003. Effects of environmental management systems on environmental management practices and operations. Production and Operations Management, 12 (3), 416-431.

Teece, D. J., 2007. Explicating Dynamic Capabilities: the Nature and Microfoundations of (Sustainable) Enterprise Performance. Strategic Management Journal, 28, 1319-1350.

Teece, D. J., Pisano, G., Shuen, A., 1997. Dynamic capabilities and strategic management. Strategic Management Journal, 18 (7), 509-533.

Tice, J., Ahouse, L., Larson, T., 2005. Lean production and EMSs: aligning environmental management with business priorities. Environmental Quality Management, winter 2005, 1-12.

Todorut, A. V., 2012. Sustainable Development of Organizations through Total Quality Management. Procedia - Social and Behaviral Sciences, 62, 927-931.

Tomsic, N., Bojnec, S., Simcic, B., 2015. Corporate sustainability and economic performance in small and medium sized enterprises. Journal of Cleaner Production, 1-10.

Torugsa, N. A., O’Donohue, W., Hecker, R., 2012. Capabilities, Proactive CSR and Financial Performance in SMEs: Empirical Evidence from an Australian Manufacturing Industry Sector. J. Bus. Ethics, 109, 483-500.

Vallance, S., Perkins, H. C., Dixon, J. E., 2011. What is social sustainability? A clarification of concepts. Geoforum, 42, 342-348.

Vanpoucke, E., Vereecke, A., Wetzels, M., 2014. Developing supplier integration capabilities for sustainable competitive advantage: a dynamic capabilities approach. Journal of Operations Management, 32, 446-461. 
Verrier, B., Rose, B., Caillaud, E., Remita, H., 2014. Combining organizational performance with sustainable development issues: the lean and green project benchmarking repository. Journal of Cleaner Production, 85, 83-93.

Waddock, S. A., Graves, S. B., 1997. The Corporate Social Performance - Financial Performance Link. Strategic Management Journal, 18 (4), 303-319.

Wagner, M., 2010. The Role of Corporate Sustainability Performance for Economic Performance: A Firm-level Analysis of Moderation Effects. Ecological Economics, 69, 1553-1560.

Wagner, M., Blom, M., 2011. The Reciprocal and Non-linear Relationship of Sustainability and Financial Performance. Business Ethics: A European Review, 20 (4), 418-432.

Wang, C. L., Ahmed, P. K., 2007. Dynamic Capabilities: A Review and Research Agenda. International Journal of Management Reviews, 9 (1), 31-51.

Wang, T., Bansal, P., 2012. Social Responsibility in New Ventures: Profiting from a Long-term Orientation. Strategic Management Journal, 33, 1135-1153.

Wilhelm, H., Schlomer, M., Maurer, I., 2015. How dynamic capabilities affect the effectiveness and efficiency of operating routines under high and low levels of environmental dynamism. British Journal of Management, 26, 327-345.

Winter, S., 2003. Understanding Dynamic Capabilities. Strategic Management Journal, 24 (10), 991-995.

Wong, C. W. Y., Lai, K., Shang, K., Lu, C., Leung, T. K. P., 2012. Green operations and the moderating role of environmental management capability of suppliers on manufacturing firm performance. Int. J. Production Economics, 140, 283-294.

World Commission on Environment and Development (WCED), 1987. Our Common Future. Oxford: Oxford University Press.

Wu, Q., He, Q., Duan, Y., O’Regan, 2012. Implementing Dynamic Capabilities for Corporate Strategic Change toward Sustainability. Strategic Change, 21, 231-247.

Wu, S. J., Melnyk, S. A., Flynn, B. B., 2010. Operational Capabilities: the Secret Ingredient. Decision Sciences, 41 (4), 721-754. 
Xia, X., Govindan, K., Zhu, Q., 2015. Analyzing internal barriers for automotive parts remanufacturers in China using Grey-DEMATEL approach. Journal of Cleaner Production, 87, 811-825.

Yang, C-S., Lu, C-S., Haider, J. J., Marlow, P. B., 2013. The Effect of Green Supply Chain Management on Green Performance and Firm Competitiveness in the Context of Container Shipping in Taiwan. Transportation Research Part E: Logistics and Transportation Review, 55, $55-73$.

Yang, L., 2013. Key Practices, Manufacturing Capability and Attainment of Manufacturing Goals: the Perspective of Project/Engineer-to-order Manufacturing. International Journal of Project Management, 31, 109-125.

Yang, M. G., Hong, P., Modi, S. B., 2011. Impact of Lean Manufacturing and Environmental Management on Business Performance: An Empirical Study of Manufacturing Firms. Int. J. Production Economics, 129, 251-261.

Yu, W., Ramanathan, R., Nath, P., 2014. The Impacts of Marketing and Operations Capabilities on Financial Performance in the UK Retail Sector: A Resource-based Perspective. Industrial Marketing Management, 25-31.

Zeng, S. X., Meng, X. H., Yin, H. T., Tam, C. M., Sun, L., 2010. Impact of Cleaner Production on Business Performance. Journal of Cleaner Production, 18, 975-983.

Zhu, Q., Cordeiro, J., Sarkis, J., 2012. International and Domestic Pressures and Responses of Chinese Firms to Greening. Ecological Economics, 83, 144-153.

Zhu, Q., Sarkis, J., Lai, K., 2013. Institutional-based Antecedents and Performance Outcomes of Internal and External Green Supply Chain Management Practices. Journal of Purchasing \& Supply Management, 19, 106-117.

Zink, K. J., 2007. From Total Quality Management to Corporate Sustainability Based on a Stakeholder Management, Journal of Management History, 13 (4), 394-401. 